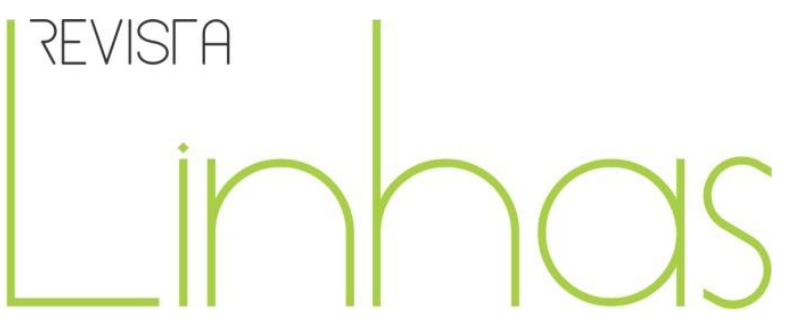

\title{
Razões para comemorar: o legado das festas de aniversário da centenária Escola Regional de Merity
}

\section{Resumo}

A Escola Regional de Merity, criada em Duque de Caxias, Baixada Fluminense, por Armanda Álvaro Alberto - educadora, feminista e militante política - chega ao seu centésimo aniversário cercada de homenagens. Partindo da compreensão de que comemorar envolve refletir sobre o passado, interrogar o presente e projetar o futuro, o presente texto se volta para as festas de aniversário da escola, registradas em fotografias, discursos e depoimentos orais, sem perder de vista outras celebrações que implicaram reunir, rememorar, ensinar. Por fim, levanta os sentidos que envolvem as comemorações do centenário.

Palavras-chave: Escola Regional de Merity; Armanda Álvaro Alberto; centenário; comemoração.

\section{Ana Chrystina Mignot}

Universidade do Estado do Rio de Janeiro - UERJ - Rio de Janeiro/RJ Brasil acmignot@terra.com.br

\section{Para citar este artigo:}

MIGNOT, Ana Chrystina. Razões para comemorar: o legado das festas de aniversário da centenária Escola Regional de Merity. Revista Linhas. Florianópolis, v. 22, n. 50, p. 12-28, set./dez. 2021. 


\title{
Reasons to celebrate: the legacy of anniversary celebrations in centennial Merity Regional School
}

\begin{abstract}
Merity Regional School - which was launched in Duque de Caxias County, Baixada Fluminense, by educator, feminist and political activist Armanda Álvaro Alberto has celebrated its hundredth anniversary surrounded by tributes. Based on the understanding that celebrating also means reflecting about the past, questioning the present and planning the future, the aim of the present study is to analyze anniversary celebrations in Merity Regional School, which were recorded in photographs, speeches and oral testimonials, although without losing sight of other celebrations that implied gathering, recalling and teaching. Finally, it addresses the meaning of celebrating hundredth anniversaries.
\end{abstract}

Keywords: Merity Regional School; Armanda Álvaro Alberto; hundredth anniversary; celebration. 
Criada em 1921, por Armanda Álvaro Alberto - educadora, feminista, prisioneira política, fundadora da Associação Brasileira de Educação ( $A B E)^{1}$, signatária do Manifesto dos Pioneiros da Educação $\mathrm{Nova}^{2}$, presidente da União Feminina do Brasil (UFB) ${ }^{3}$ - no então município de São João de Meriti, atualmente Duque de Caxias, na Baixada Fluminense, um lugar pobre, esquecido do poder público e povoado por nordestinos que fugiam da seca, da miséria e da fome, a Escola Regional de Merity chega ao seu centésimo aniversário, cercada de homenagens, apesar da pandemia que impede realizar presencialmente cerimônias festivas para marcar e enaltecer a data.

A impossibilidade de reencontro nos moldes dos anos anteriores merece um lamento, pois, durante o passar do tempo, o aniversário da escola não passava despercebido por aqueles que a viram surgir, crescer e lutar por permanecer viva, o que instiga a refletir sobre os significados de comemorar. De origem latina - commemorare etimologicamente, quer dizer "trazer à memória. Commemorare também significa commemorare, isto é, recordar com, recordar junto com o outro" (MORAES e NACIMENTO, 2008, p. 1). Alguns depoimentos de antigos alunos dão conta de que a escola inicialmente Escola Proletária de Merity, posteriormente Escola Regional de Merity, Escola Dr. Álvaro Alberto, Escola Municipal Dr. Álvaro Alberto, atual Creche Escola Dr. Álvaro Alberto - que foi mudando de nome, sempre encontrou razões para o reencontro de celebração da data. Até mesmo a festa de despedida de sua diretora, em 1964, se constituiu em justificativa para reunir alunos e professoras para evocar as primeiras e

\footnotetext{
${ }^{1}$ Sobre a Associação Brasileira de Educação (ABE) consultar CARVALHO, Marta Chagas de. Molde nacional e fôrma cívica: higiene, moral e trabalho no projeto da Associação Brasileira de Educação (1924-1931). Bragança Paulista: Editora Universidade de São Francisco, 1998.

${ }^{2}$ Além de Armanda Álvaro Alberto, o Manifesto dos Pioneiros da Educação Nova teve os seguintes signatários: Fernando de Azevedo, Afrânio Peixoto, A. de Sampaio Dória, Anísio Spínola Teixeira, M. Bergström Lourenço Filho, Roquette Pinto, J. G. Frota Pessôa, Julio de Mesquita Filho, Raul Briquet, Mario Casassanta, C. Delgado de Carvalho, A. Ferreira de Almeida Jr., J. P. Fontenelle, Roldão Lopes de Barros, Noemy M. da Silveira, Hermes Lima, Attilio Vivacqua, Francisco Venâncio Filho, Paulo Maranhão, Cecília Meireles, Edgar Sussekind de Mendonça, Garcia de Rezende, Nóbrega da Cunha, Paschoal Lemme e Raul Gomes. Sobre seu significado e importância, consultar, dentre outros, XAVIER, Libânia N. Para além do campo educacional: um estudo sobre o Manifesto dos Pioneiros da Educação Nova (1932). Bragança Paulista: Editora Universidade de São Francisco, 2002 e VIDAL, Diana. 80 anos do Manifesto dos Pioneiros da Educação Nova: questões para debate. Educação e Pesquisa, São Paulo, USP, v. 39, n. 3, p. 577-588, jul./set. 2013.

${ }^{3}$ A União Feminina do Brasil (UFB) se constituiu em entidade feminista para a defesa dos direitos políticos das mulheres. Criada em 1935, tinha o intuito de lutar contra a discriminação da mulher que se expressava na legislação. Enquanto presidente da entidade, Armanda advogou que, assim como a Aliança Nacional Libertadora (ANL), ela fosse também uma frente única de todas as mulheres, sem distinção social, religiosa, econômica, racial e política cf. MIGNOT, Ana Chrystina. Baú de memórias, bastidores de histórias: o legado pioneiro de Armanda Álvaro Alberto. Bragança Paulista: EDUSF, 2002.
} 
gloriosas iniciativas, quando traziam à tona o porquê de tanto se orgulharem da escola onde haviam estudado ou trabalhado:

Quando estive na Europa, me mostraram métodos de ensino adiantadíssimos. Os senhores não imaginam o que eu senti quando verifiquei que os métodos da Escola que o povo chamava de mate com angu estavam além dos métodos europeus. Mate com angu era como nos chamavam na rua, mas eles sabiam que nós não ligávamos para o apelido, não ligávamos porque éramos felizes. (TRINDADE, Raquel. 1968, p. 173)

Assim como no depoimento da ex-aluna, a escola era exaltada por seus contemporâneos pelo muito que contribuiu para a construção da Escola Nova no país. Aliás, sua fundadora chegou a ser comparada, por ocasião do quadragésimo aniversário da escola, por Paschoal Lemme - um dos signatários do Manifesto dos Pioneiros da Educação Nova- a uma das educadoras mais conhecidas internacionalmente por seu trabalho em um bairro popular italiano: “ $D$. Armanda Álvaro Alberto pode ser comparada sem favor, no plano brasileiro, às maiores figuras da pedagogia contemporânea e cognominada, sem exagero, a Montessori brasileira".

Comemorações faziam parte dos rituais da escola. Durante o início do período republicano, além das datas cívicas, a inauguração das escolas era cercada de festividades "para celebrar os aspectos que ainda eram novidades na cultura das escolas públicas primárias, dando visibilidade ao modelo de educação escolar inspirado em países considerados civilizados, como França, Inglaterra, Suíça, Alemanha, entre outros", assinalam Gallego e Cândido (2015, p. 29). Lembram ainda que os aniversários das instituições escolares também se constituíam em importantes momentos de comemoração:

Festejava-se para civilizar, divulgar, inaugurar e encerrar o ano letivo. Contrariando a ideia de que o tempo da festa é somente um tempo de descontração e divertimento, as festas escolares constituíam-se tempo de aprender. O exame dos programas, nos quais se propunha a organização dos dias de festa, e das sugestões de atividades a serem realizadas nas comemorações, ambos publicados em revistas especializadas, evidencia o caráter pedagógico das festas, pois estas buscavam ensinar às crianças e aos adultos presentes em tais ocasiões a representatividade de cada data, bem como os valores e as virtudes 
associados ao novo regime político - a República. (GALLEGO; CANDIDO, 2017, p. 23)

Comemorar o centenário da Escola Regional de Merity implica assumir de saída que nem sempre sua importância na cena educacional mereceu atenção, pois permaneceu esquecida e à margem da historiografia da educação até finais da década de 1980, quando houve uma inflexão na historiografia e na historiografia da educação que passou a eleger as mulheres, os livros, a leitura e as crianças entre os objetos de investigação, bem como passado a valorizar novas fontes de pesquisa, deixando de focalizar somente a legislação, as reformas de ensino e os reformadores, e se voltaram para outros espaços de atuação nos quais as mulheres tiveram protagonismo no cotidiano das associações e nas lutas políticas mais amplas da sociedade.

Também se pode dizer que comemorar é fazer o balanço do vivido, refletir sobre o presente e projetar o futuro ${ }^{4}$. Tomando tal compreensão como fio condutor, recorro a variados registros de momentos solenes. Elejo fotografias reunidas em álbuns ou avulsas, dentro de envelopes, anotadas, legendadas ou datadas, entendendo que elas sintetizam o legado e funcionam como artifícios para fixar a memória, impedir o esquecimento e assegurar um lugar na posteridade. Entrecruzadas com outros documentos e depoimentos sobre os aniversários da escola, convidam a não perder de vista outras celebrações que envolveram reunir, rememorar, ensinar.

\section{Em meio às festividades}

Dentre as fotografias que ocupam um lugar especial no arquivo pessoal de Armanda Álvaro Aberto e que permitem percorrer a história da Escola Regional de Merity, encontram-se aquelas que registram os aniversários daquele que seria um modelo de educação popular, ao lado de outras que focalizam cenas do cotidiano, visitas de professoras e autoridades, reuniões do Círculo de Mães, inauguração de prédios escolares. Guardadas cuidadosamente, eternizam momentos significativos da experiência, permitindo dar a conhecer, provar, inspirar.

\footnotetext{
4 “Comemorar é refletir, é fazer o balanço obrigatório do passado, é avaliar o presente, em transformação, é imaginar o futuro desejado" (MOTTA, 1994, p. 66).
} 
Assim como tantos outros documentos, instigam interrogá-las na medida em que congelam no papel momentos especiais: as festas, que "têm significados diversos para diferentes sociedades, desde manifestações da felicidade coletiva, homenagens, rituais de passagem do tempo, até a reconstrução do imaginário político e social dos cidadãos" (OLIVEIRA, 2018, p. 14). Entendidas como expressão da cultura escolar, as comemorações integram o calendário escolar trazendo "uma historicidade que diz muito sobre a sociedade em que a escola está inserida", permitindo compreender "as nuances que permeiam sua organização e sua execução" (idem). Algumas foram publicadas na imprensa e em livros visando dar visibilidade ao projeto educacional voltado para as crianças pobres, negras e descalças que habitavam uma das regiões mais populosas do estado do Rio de Janeiro, na Baixada Fluminense.

A cada ano, a data significava a possibilidade de perpetuar na lembrança o início das atividades de uma escola em cerimônia na qual compareceram Edgar Sussekind de Mendonça e Francisco Venâncio Filho que testemunharam a inauguração de uma instituição considerada como agente do progresso, da nação moderna. No relatório do primeiro ano de funcionamento, eles são apontados como os principais colaboradores juntamente com aqueles que apoiavam financeiramente a escola: a Liga Brasileira Contra o Analfabetismo, Corina Barreiros, Maria dos Reis Santos, Lizinha Pereira Pinto, Laura Brandão, Maria Gomes, Antonia Venâncio, Viúva Álvaro Alberto, Therezita Álvaro Alberto, Fonseca e Silva, Dr. Ernesto de Otero, Comandante Álvaro Alberto e Edgar Süssekind de Mendonça, além das meninas Elizabeth Otero e Lucy Hentz, mais outras alunas do Curso Jacobina e Roquette-Pinto que colaborava, com exemplares para o museu escolar, dentre outros. 
Figura 1 - Inauguração da escola, 13 de fevereiro de 1921

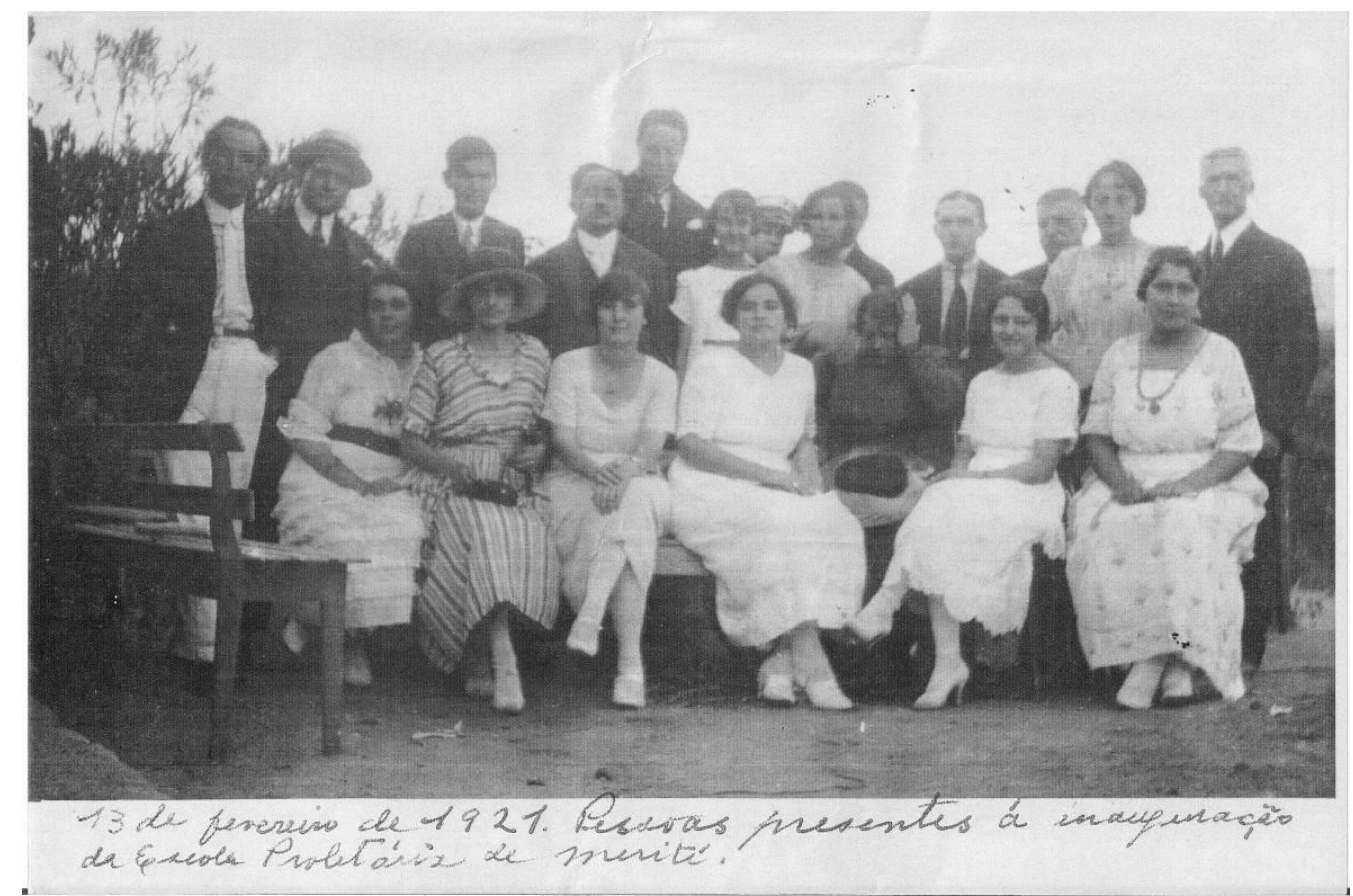

Fonte: Arquivo pessoal de Armanda Álvaro Alberto (PROEDES-UFRJ).

A inauguração dessa escola, a exemplo de tantas outras que passaram a funcionar neste período, trazia alguns significados. Ali seria construída uma escola nova, diferente, baseada nos interesses e necessidades das crianças, partindo do próximo e do concreto para o distante e o abstrato, como eixo metodológico. Uma escola rural, gratuita e sem fins lucrativos, voltada para as crianças do povo, sem privilégios nem discriminações, sem prêmios nem castigos. Uma escola que, para existir, precisava do apoio financeiro e pedagógico de outros educadores. Uma escola que fosse permanentemente aberta à comunidade. Este, mais do que um projeto particular, era um projeto coletivo de educadores daquela geração que pretendiam fazer da escola um espaço para instruir, educar e civilizar.

Justificava-se, assim, a cada ano, reviver aquele momento solene que sintetizava a realização de uma experiência de regeneração da sociedade pela via da escola que viria com o passar do tempo se consagrar na cena educacional. Compreendidas como “emissoras de uma linguagem coletiva que não deixa de lado sua característica primaz [de]expressar planos simbólicos diversos, apreendidos por aqueles que delas têm algum tipo de participação, quer sejam como organizadores, personagens ou expectadores" (BENCOSTA, 2006, p. 3858). As festas de aniversário da Escola Regional de Merity 
permitem interpretar que os discursos proferidos e as atividades realizadas objetivavam comprovar que ali se realizava um dos mais autênticos ensaios de Escola Nova no país, que mereceu referências feitas por Fernando de Azevedo, Lourenço Filho e Paschoal Lemme, bem como crônica de Júlia Lopes de Almeida que exaltava o caráter missionário de Armanda como "uma das mais inteligentes e mais cultas das nossas patrícias, de cuja mocidade irradiante se estende em largo círculo uma claridade fecunda e civilizadora" (ALMEIDA, 1968, p. 59)e de outros que afirmavam a dimensão patriótica e heroica de sua fundadora por ser ela uma "moça de aparência frágil e ânimo de apóstolo", cuja "verdadeira catequese cívica" servia de exemplo para outras mulheres (CAPISTRANO, 1924, p. [12]).

Lembrar a passagem do tempo não se resumia a festejar. Além do aniversário da escola, Armanda encaminhava aos colaboradores e, por vezes, à imprensa carioca, um relatório anual no qual destacava as realizações, desafios, dificuldades e projetos que permaneciam. Ao receber um deles, Carlos Drummond de Andrade escreveu "Uma escola vive":

Se os relatórios burocráticos são sempre envoltos numa camada de tédio, há outros, os escolares, que podem oferecer-nos a sugestão dos documentos sociológicos e mesmo o interesse dos romances. Contar a vida de uma escola durante um ano, é tarefa que deveria seduzir o escritor, ou despertar em quem não o fôsse o desejo de sê-lo, porque nada há mais vivo e rico de humanidade, mais cheio de problemas e sugestões, do que o funcionamento da comunidade escolar. Necessariamente, a narrativa do ano letivo será tanto mais palpitante quanto for a integração da escola nos seus verdadeiros fins, porém mesmo da escola triste, mal dirigida e de nenhum rendimento, se poderá fazer uma pintura impressionante, que desperte no leitor o sentimento de curiosidade e, mais, o de solidariedade com a pobre infância que ali se destrói.

O relatório não é, pois em si, coisa enfadonha. Saiba-se escrevê-lo, saibase ver o que está aí para ser visto, sentido e interpretado e logo se conseguirá isto que aparentemente é tão difícil: interessar o povo na vida escolar. [...]

Muito bem, d. Armanda Álvaro Alberto. (ANDRADE,1945, [p. 12])

Nesses relatórios havia quase sempre uma alusão à comemoração do aniversário da Escola Regional de Merity. A ex-aluna Maria José Trindade Dutra que nela estudou em 1936 e 1937 se lembrava de uma das festas, sugerindo que aquela ocasião servia para promover o encontro de visitantes ilustres que chegavam da capital da República. Eram 
amigos, colaboradores, alunos, ex-alunos e suas famílias. Aqueles momentos festivos serviam para exibir inovadores métodos de ensino que se contrapunham ao antigo verbalismo ainda predominante, reafirmar a crença na indissociabilidade do trabalho manual e intelectual e demonstrar que a escola deveria ser o centro da atividade cultural de uma comunidade:

Todos os anos em setembro era festa da escola, aniversário da escola. [...] Foi criada em fevereiro mas a festividade era em setembro. Sempre foi em setembro. E, então, tinha aula de trabalhos manuais junto com as Mães do Círculo de Mães, então estes trabalhos eram vendidos, né? Era exposição para o pessoal do Rio que vinha... Todo pessoal importante: professores, velhos amigos de Dona Armanda, né? Então era um dia de festa! Então, neste dia, a gurizada estava atenta ali, né? Para cantar, para fazer teatrinho e... enfim, prestigiar os seus convidados informação fornecida por Maria José Trindade Dutra em entrevista realizada na cidade de Duque de Caxias em setembro de 1989)

Mas, nem sempre as comemorações diziam respeito ao início e término do ano letivo ou aniversário da escola. No ano de 1937, por exemplo, outro acontecimento, devidamente registrado para a posteridade, mereceu celebração: a volta de Armanda Álvaro Alberto para a escola, depois de longos meses que estivera afastada, pois se tornara prisioneira política sob a acusação de envolvimento nos acontecimentos de novembro de 1935, por presidir a União Feminina do Brasil (UFB), uma entidade que defendia os direitos civis e políticos das mulheres, que não escapou do fechamento, nos tempos sombrios que se abateram sobre o país, sob a alegação de que desenvolvia atividades subversivas. Juntamente com Maria Werneck de Castro, Beatriz Bandeira Riff, Eugênia Álvaro Moreira, Eneida de Moraes, Nise da Silveira e Olga Benário, foi uma das mulheres vítimas do arbítrio e estava entre aquelas que não escaparam da censura, da perseguição e da prisão. Durante a “onda de terror" na qual nada detinha o governo diante do que representasse ameaça à ordem social, quando "a selvageria policial não respeitou nem categoria social, nem idade, nem sexo", como assinalou Leôncio Basbaun (1962, p. 96), elas foram privadas de liberdade. 
Figura 2 - Volta à escola depois da saída da prisão política. $1^{\circ}$ de agosto de 1937

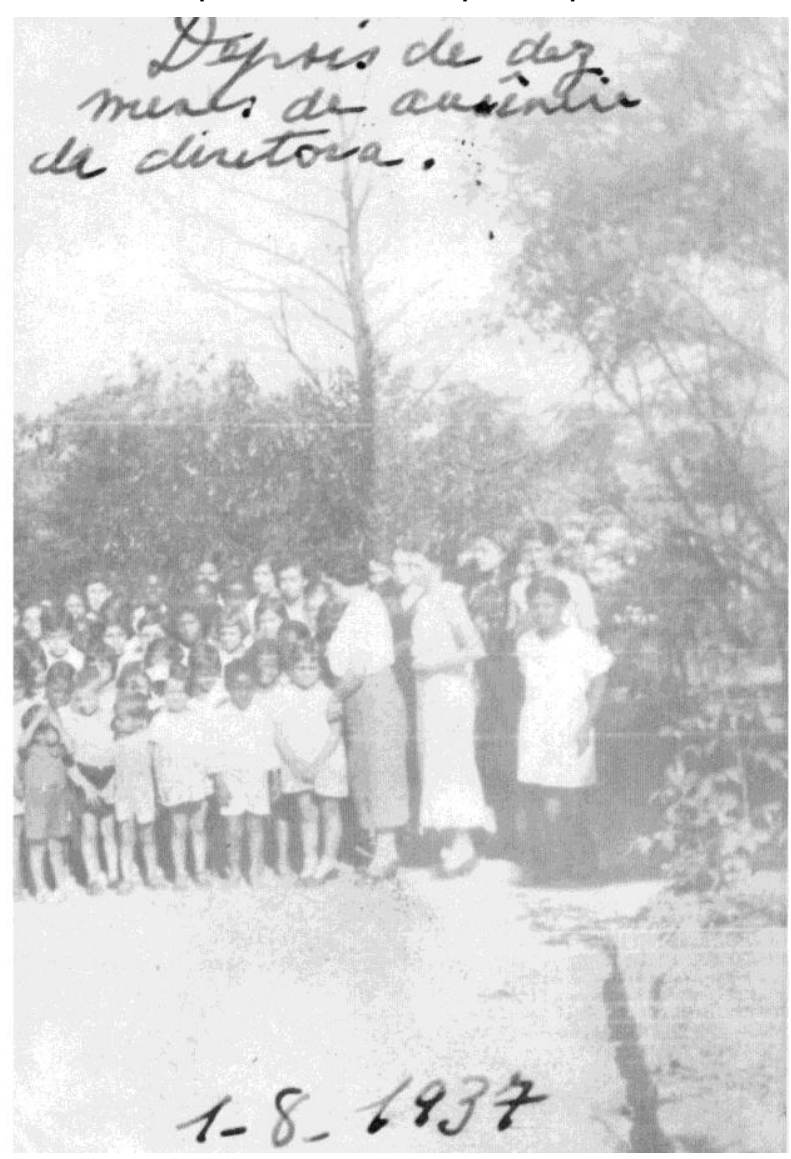

Fonte: arquivo pessoal de Armanda Álvaro Alberto (PROEDES-UFRJ).

O retorno à escola significou a possibilidade de dar prosseguimento aos projetos de ampliar a biblioteca escolar, cuidar das questões financeiras que ameaçavam sua sobrevivência e, sobretudo, retomar o convívio com as professoras, as mães e as crianças, mas estas últimas desconheciam os motivos da prolongada ausência, como testemunhou Maria José Trindade Dutra:

Minha irmã ia visitá-la onde ela ficava prisioneira. E ela levava os trabalhos dos alunos para ela corrigir, para ela acompanhar todo aquele processo. [...] eles escondiam até de nós, das crianças. Os adultos escondiam de nós esta fase triste da vida de Dona Armanda que ela ficou prisioneira até com a esposa do Carlos Prestes, a Olga, não é a Olga? [...] não sei porque escondiam dos alunos. E nós não sabíamos desta passagem da Dona Armanda. Só sabíamos que estava doente, né? Que estava doente e que nós tínhamos que mandar os trabalhinhos. (informação fornecida por Maria José Trindade Dutra em entrevista realizada na cidade de Duque de Caxias em setembro de 1989) 
Obedecendo ao ritmo do tempo, o calendário escolar definia datas significativas como momentos solenes destinados a rememorar, a imprimir significados às experiências, a construir uma representação da instituição de ensino que rompera com as práticas tradicionais, baseada em princípios que a transformaram em modelo a ser seguido, imitado, preservado. Assim, ao longo dos anos, outras comemorações seriam realizadas na escola: o jubileu de prata (1946), o jubileu de ouro (1971), a festa de despedida (1964) e até mesmo o aniversário de 80 anos da fundadora (1972), dois anos antes de sua morte, deixando entrever que a vida pessoal e a vida profissional estavam intimamente entrelaçadas.

De diversos modos, os dias festivos serviam de pretexto para render homenagens à escola e sua fundadora, sempre lembrada por seu compromisso social com os mais pobres, com o respeito que conquistara na cena educacional e com o reconhecimento nacional e internacional de sua obra graças aos métodos inovadores baseados em princípios democráticos que subvertiam as relações de autoridade nas salas de aula. Também serviam de pretexto para reunir os alunos, os ex-alunos e suas famílias, os antigos e os novos colaboradores que garantiam a sobrevivência financeira da escola, além de velhos amigos com os quais havia compartilhado ideais de educação. Essas ocasiões serviam para reafirmar bandeiras de luta que amalgamaram essa geração de educadores: uma escola laica, gratuita, de qualidade para todos, pontos basilares que permitiram fundar associações, assinar manifestos em defesa da educação, enfrentar os debates com os católicos, seguir em frente mesmo nos momentos sombrios de discussões acaloradas.

Em 1951, foram festejados os 30 anos da Escola, quando na frente do prédio foi inaugurado um marco em forma de livro de bronze sobre um pedestal. Mandado construir pelos antigos alunos, ali permanece para lembrar a todos que entram ser este um espaço de conhecimento, de cultura, de leitura, de transmissão da ciência. 
Figura 3 - Armanda Álvaro Alberto na inauguração de um pedestal na entrada da Escola Regional de Merity, marco do trigésimo aniversário

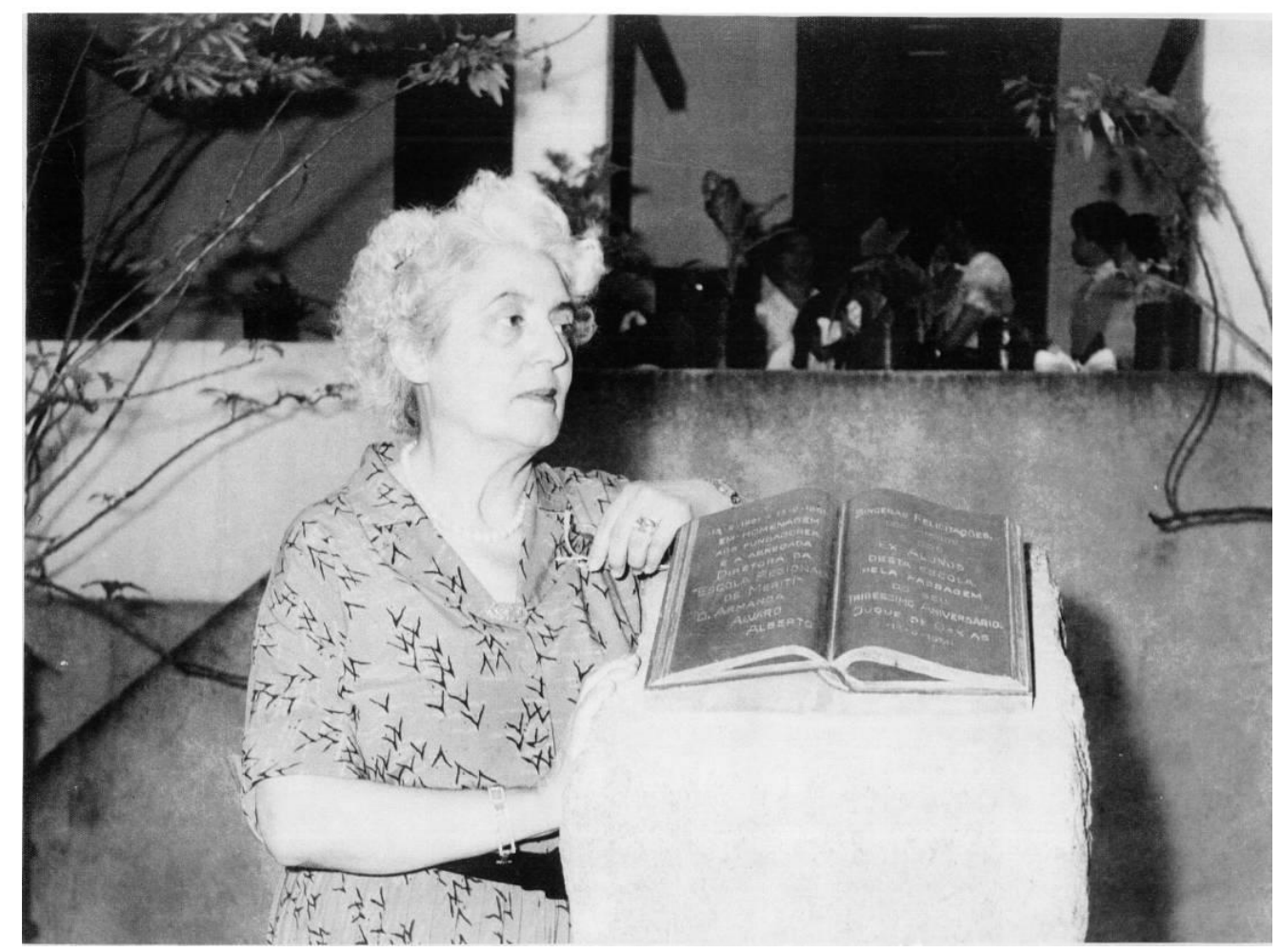

Fonte: Arquivo pessoal de Armanda Álvaro Alberto, (PROEDES-UFRJ).

Mas, a escola não foi o único espaço de celebração do aniversário. Na Associação Brasileira de Educação ( $A B E)$ - da qual Armanda Álvaro Alberto foi sócio-fundadora, membro da diretoria, presidente da entidade e presidente da Secção de Cooperação da Família, liderando inquéritos de leituras, organizando exposições de livros infantis, assinando manifestos aos editores, procurando, enfim, interferir na política editorial e na política de construção de bibliotecas públicas e escolares - por ocasião dos 40 anos de fundação da Escola Regional de Merity, recebeu homenagem, quando ela já pensava em se afastar das atividades e pretendia transferir sua escola para o governo estadual, o que veio a ser uma tentativa frustrada. Somente em 1968 conseguiu passá-la aos cuidados do Instituto Central do Povo, ligado à Igreja Metodista. Paschoal Lemme, o mais jovem dos signatários do Manifesto dos Pioneiros da Educação Nova recebeu a incumbência de proferir o discurso naquela solenidade e, em meio à rememoração dos velhos tempos, destacou a importância da experiência e a necessidade de preservá-la: 
Tal como a barraca de Euclides da Cunha, à beira do Rio Pardo, onde o monumento de Os Sertões foi concebido e escrito, e que o governo envolveu em sua proteção carinhosa, pelo muito que representou para a nacionalidade, a Escola Regional de Meriti está a merecer também a atenção das autoridades, não para rodeá-la de vidro, nem para transformá-la em museu, como a lasnaia Poliana, de León Tolstói, mas para apresentá-la com toda a sua plenitude, dando-lhe recursos para a sua sobrevivência, para completar seus planos, transformando-a numa verdadeira instituição de caráter experimental, onde o professorado irá receber a inspiração de métodos progressistas de ensino e de educação, uma instituição nascida do ideal e do sonho, forjada na luta com a prática e com a realidade. (LEMME, 1968, p. 172)

\section{Comemorar o centenário}

O centenário de uma escola fundada na região metropolitana do Rio de Janeiro, a Escola Regional de Merity, merece comemoração e, neste sentido, instiga a refletir sobre a importância da experiência pedagógica na cena educacional, interrogando o legado com olhos voltados para os desafios do presente com vistas a um futuro no qual a educação, entendida como ato político, seja sempre e cada vez mais um direito de todos. Tal como as celebrações anteriores, o seu centésimo aniversário também vem revestido de simbolismos, representações e valores a inculcar ou cultivar.

Se comemorar significa, "trazer à memória, fazer recordar", "solenizar a recordação de algum fato ou de alguma pessoa" ou "festejar com comemoração" (MICHAELIS, C2021), celebrar o centenário implica trazer à tona os momentos festivos registrados em fotografias que visam aprisionar o vivido, fixar a memória e impedir o esquecimento para identificar os herdeiros desse legado deixado por Armanda Álvaro Alberto. Passeio por imagens e papéis e, inicialmente, vejo que são todos os moradores de Duque de Caxias, cidade que a acolheu permitindo realizar os sonhos de juventude; os ex-alunos da escola que experimentaram práticas pedagógicas inovadoras; as professoras que aceitaram participar de uma escola nova e diferente, pois elegeu as crianças pobres como as favoritas. Também vislumbro os pesquisadores que se debruçam sobre os vários documentos deixados para perscrutar a relevância da escola e de sua fundadora na cena educacional de seu tempo. Afinal, 
comemoração oferece a possibilidade ímpar de viver, observar e analisar os trabalhos e a arte da memória, pelo que seleciona como pelo que procura apagar; pelo que celebra como pelo que relega ao esquecimento; pelo que repete à saciedade como pelo que omite; pelo que monumentaliza como pelo que pretende destruir; pelo que recolhe do passado como pelo que projeta para o futuro; pelos que protagonizam a festa e nela ocupam o proscênio como pelos que são convidados a, docilmente, assisti-la aplaudindo nos momentos apropriados. Porque comemorar é sempre construir uma memória comum, vale dizer, uma identidade coletiva e um projeto de futuro, para recolher toda a riqueza sugerida na articulação entre memória, identidade e projeto[...]. E porque os trabalhos e as artes da memória são sempre múltiplos, complexos e surpreendentes. (NEVES, 2000, p. 12)

Desse modo, comemorar o centenário da Escola Regional de Merity significa pensar que não se trata de reavivar nostalgicamente um passado distante e idilicamente construído como melhor, perfeito e a ser restaurado. Envolve interpretar como manter vivos alguns princípios que deram vida e razão de existência à escola que sobreviveu ao desgaste do tempo, ao esquecimento e aos parcos recursos financeiros destinados à educação.

Assim, compete aos moradores de Duque de Caxias - muitos reunidos em associações, sindicatos atuantes e órgãos públicos - lutar para manter o prédio escolar, um patrimônio da cidade, projetado por Lúcio Costa, que guarda em seus muros uma história de lutas em favor de uma educação laica, gratuita e de qualidade para todos. Implica também em exigir do poder público mais do que a manutenção arquitetônica, pois uma escola não existe apenas de cimento e tijolos. Ela precisa de uma política voltada para a formação permanente e continuada de professores bem remunerados, ambientes alegres e materiais didáticos diversificados para que não se perca de vista um dos mais importantes legados desta escola: educação é um direito de todos.

Aos antigos alunos que desfrutaram da presença de Armanda Álvaro Alberto e que dela se recordam como uma profissional competente e comprometida com as causas sociais compete contar sua história, contar novamente e mais uma vez, para manter na memória a necessidade de fazer desta e de outras escolas um espaço de liberdade, de democracia, de aprendizado de vida, experimentação e solidariedade. 
As professoras convidam e estão convidadas a compartilhar a compreensão que Armanda Álvaro Alberto tinha do exercício do magistério, mantendo no horizonte suas palavras que exaltavam o diálogo com os alunos como indispensável ao fazer docente:

Sejam, entretanto, as professoras, o que precisam ser - amigas de mais idade e experiência, que sabem e às vezes também não sabem, não se acanhando de pesquisar ao lado dos alunos, de aprenderem, mesmo com eles, as coisas todas da região que conhecem desde pequeninos...

Amigas discretas que, ao apresentar um plano de coisas a estudar, esperam sugestões, discutem com os alunos os detalhes de execução, respondem a perguntas muito mais do que perguntam, na atitude de quem encaminha o aprendizado, sem o autoritarismo de quem dá lições... Amigas que sabem deixar cada um dar tudo de si, satisfeita do esforço próprio...

Sejam as professoras essas camaradas que ensinam como querem que as crianças aprendam - fazendo. Sejam capazes de encontrar a sua própria infância na infância delas, e corram, e brinquem no meio delas...

Sejam as professoras as trabalhadoras conscientes e alegres do seu trabalho, trabalho que as identifica inteiramente com as aspirações sociais que nutrem para os seus alunos, e pouco a pouco aquelas linhas ideais, que já se deixam entrever, mas ainda não fixadas, se fixarão. (ÁLVARO ALBERTO, 1968, p. 54-55)

Essa comemoração diz respeito também às instituições de guarda, na medida em que localizam, selecionam, elegem, classificam e interpretam novos documentos, como cadernos escolares, folhas avulsas, bilhetes, fotografias, que chegam sempre acompanhados de relatos em tom de afeto e repletos de saudades, para serem disponibilizados e interrogados visto que guardam projetos e práticas de um tempo pretérito que não volta mais, mas que precisa se dar a conhecer e questionar.

Comemorar o centenário da Escola Regional de Merity é uma convocação para lutar contra o preconceito racial, social, religioso e político; advogar a importância da escola como instituição responsável pela aprendizagem da ciência, algo a ser defendido, preservado e transmitido; e sustentar o debate público sobre a necessidade de reverter o desfinanciamento da educação, da cultura e da pesquisa científica. Comemorar é tarefa polissêmica e polifônica. Dessa festa ninguém pode ser excluído. 


\section{Referências}

ALMEIDA, Júlia Lopes. Um maço de cartas. In: ÁLVARO ALBERTO, Armanda. A Escola Regional de Meriti (documentário) 1921-1964. Rio de Janeiro: MEC-INEP-CBPE, 1968. p. 5762.

ALVARO ALBERTO, Armanda. Uma experiência de escola regional. In: ALVARO ALBERTO, Armanda. A Escola Regional de Meriti (documentário) 1921-1964. Rio de Janeiro: MEC-INEPCBPE, 1968. p. 54-55.

ÁlVARO ALBERTO, Armanda. A Escola Regional de Meriti (documentário) 1921-1964. Rio de Janeiro: MEC-INEP-CBPE, 1968.

BASBAUN, Leôncio. História sincera da República: 1930-1960. São Paulo: Editora Edaglit. Edições L.B., 1962.

BENCOSTTA, Marcus Levy Albino; PEREIRA, Ana Paula Martins. Histórias, cultura e sociabilidades: representações e imagens das festas escolares (Curitiba, 1903 - 1971). In: CONGRESSO LUSO-BRASILEIRO DE HISTÓRIA DA EDUCAÇÃO, n. 6, 2006. Uberlândia, [Anais]. Uberlândia: editora, 2006. p. 3857-3868.

CAPISTRANO, H. Alma feminina. A Notícia, cidade, p. xx-xx, 25 out. 1924.

GALLEGO, Rita de Cassia e CANDIDO, Renata Marcílio. Uma discussão sobre os sentidos da integração de feriados, festas e comemorações cívicas no calendário das escolas primárias paulistas (1890-1930). Educação em Revista, Natal, v. 31, n. 2, p. 17-36, 2015.

LEMME, Paschoal. No $40^{\circ}$ aniversário de fundação da Escola Regional de Meriti. In: ÁLVARO ALBERTO, Armanda. A Escola Regional de Meriti (documentário) 1921-1964. Rio de Janeiro: MEC-INEP-CBPE, 1968, p. 163-172.

MICHAELLIS. Dicionário Brasileiro da Língua Portuguesa. [S.I.]: Melhoramentos, c2021. Disponível em:https://michaelis.uol.com.br/moderno-

portugues/busca/portuguesbrasileiro/comemorar/. Acesso em: 30 jul. 2021.

MIGNOT, Ana Chrystina. Baú de memórias, bastidores de histórias: o legado pioneiro de Armanda Álvaro Alberto. Bragança Paulista: EDUSF, 2002.

MORAES, Márcia; NASCIMENTO, Maria Lívia. Editorial. Fractal: Revista de Psicologia, Fortaleza, v. 20, n. 1, p. 1-8, jan./jun. 2008,

MOTTA, Marly Silva da. Em nome da independência, da neutralidade e da competência: os depoimentos de Octavio Gouvêa de Bulhões e de Denio Nogueira. In: FERREIRA, Marieta de Moraes. Entrevistas: abordagens e usos da história oral. Rio de Janeiro: Editora FGV, 1994. p. 65-78. 
NEVES, Margarida de Souza. A educação pela memória. Revista Teias, Rio de Janeiro, v. 1, ano 1, p. 9-15, 2000.

OLIVEIRA, Viviane Alice. A história que se ensina e se aprende nas comemorações escolares em escolas de educação básica em Xinguara - PA: festa junina, dia da independência e dia da consciência negra. 2018. Dissertação (Mestrado em Ensino de História) - Universidade Federal de Tocantins, Araguaína, 2018.

Recebido em: 18/03/2021 Aprovado em: 30/07/2021

Universidade do Estado de Santa Catarina - UDESC Programa de Pós-Graduação em Educação - PPGE 